\title{
Russian New Art of Hybrid Warfare in Ukraine
}

\author{
Soňa Rusnáková ${ }^{1}$
}

\begin{abstract}
The main aim of this paper is to analyse the annexation of Crimea by the Russian Federation. For the purposes of the paper, the theory of hybrid warfare was chosen as an analytical category. Throughout the paper, the concept of hybrid warfare is examined and applied on case study of Crimean annexation. Hybrid warfare, especially in connection with Russian actions in Crimea has been an intensely debated concept. There is an ongoing debate among scholars concerning the meaning of the concept, its existence and employment by the Russian Federation. This paper showed that the article of Valeriy Gerasimov - the incumbent Chief of the General Staff of the Russian Federation- invoked a new warfare strategy for the Russian Federation which was consequently for the very first time in its full spectre and effectivity employed on case of Crimean annexation in March 2014. Observing the application of the hybrid warfare in practice serves the purposes of countering its further potential application in post-Soviet space and Russian 'near abroad'.
\end{abstract}

Key Words: Russia, Ukraine, Crimea, hybrid warfare, annexation

\section{INTRODUCTION}

Due to its actions in Crimea which can be approached as a projection of the new capability of Russia to simultaneously employ vast spectrum of warfare means in one battlefield, the concept of hybrid warfare has become more and more interlinked with the new military thinking of Russia and most importantly, the attention was directed towards the effects this new Russian warfare style might have in the future on security of neighbouring and 'near abroad' countries. The concerns of the West elevated after the article of Russian Chief of General Staff, Valery Gerasimov - The Value of Science Is in the Foresight: New Challenges Demand Rethinking the Forms and Methods of Carrying Out Combat Operations was released in February 2013 in Russian military newspaper.

However, the opinions of scholars on the interpretation of Gerasimov vary. The article is in the West known as the 'Gerasimov's Doctrine' and considered to affirm the new orientation of Russian military operations towards hybrid warfare. According to scholars who advocate this position, due to the fact that Russia significantly lags behind the USA and NATO in terms of its conventional capabilities, it has to rely on developing rather non-conventional capabilities

\footnotetext{
${ }^{1}$ Mgr. Soňa Rusnáková, Centre for European and North Atlantic Affairs
} 
to compensate for its shortcomings. The hybrid warfare has become "Russia's new art of war" (Jones, 2014), an updated military strategy of Russian military directing its future operations. The idea that Russia could use hybrid warfare for regaining territories of post-Soviet states cannot be underestimated: “...the strategy of hybrid warfare is applicable in the former Soviet region precisely because here Russia can leverage its escalation dominance over its neighbours and its relatively better local knowledge" (Lanoszka, 2016, p. 194). Lanoszka provides four explications why post-Soviet region is in particular prone to attract hybrid style of warfare: the presence of ethnic Russian minorities in post-Soviet countries, the underlying historical grievances among post-Soviet countries of which Russia can take advantage and apply the policy of 'divide and rule', weak social network among the members of civil society and lastly, overall regional complexity which provides comparative advantage for Russia in understanding the region's realities better than any other external power (p. 194). One of the main objectives of this thesis will be to advocate this view on Russia and hybrid warfare as its new military thinking, used not only to adapt to new security era of hybrid threats, but demonstrating that Russia itself poses a serious security threat for neighbouring countries by projecting its offensive hybrid capabilities into the post-Soviet region.

Other scholars claim that "...Gerasimov is simply explaining his view of the operational environment and the nature of future war, and not proposing a new Russian way of warfare or military doctrine..." (Bartles, 2016, p. 31). According to them, the West is misinterpreting the article and is overanalysing it since the article is merely a foresight on how future military operations are and will be in general conducted worldwide. They refuse to admit that the article establishes a guide on how Russia will wage warfare: "'Hybrid war' can hardly be considered a definitive doctrine for Russia's future power projection in its neighborhood, much less a model that could be easily reproduced in far flung and diverse corners of the post-Soviet space" (Kofman and Rojansky, 2015, p. 1). Moreover, they agree that the intervention in Crimea and Ukraine was unique in context and circumstances so "...the chances that it could simply repeat a Crimea or a Donbas scenario elsewhere are, fortunately, low" (p. 7). McDermott (2016) further adds to these perceptions that

Among these untested and certainly unproven assertions are the ideas that Moscow has developed a doctrine and operational strategy referred to as "hybrid warfare," or that its operations in Ukraine can be explained by reference to new and evolving defense and security capabilities. Unfortunately, hybrid warfare is an alien concept in Russian military theory and in its approach to modern warfare...(p. 97). 
What is also worth to mention is another substantial distinction in the Western and Russian perception concerning the concept of the 'soft power'. Usually the elements of unconventional/irregular/non-linear operations such as diplomatic, political, economic, social, financial, information and psychological ones can be regarded as falling under the category of soft power. However, the understanding of these means and their range varies between the West and Russia. As Meister and Puglierin (2015) suggest, “...the EU uses soft power to try to strengthen the civil societies in those countries, support independent media, and help the democratic transformation process expand to the east" (p. 1). Such understanding is in contrast with the Russian approach because it is based rather on attraction than coercion. These actions are evaluated by Russia as threatening its state interests and undermining its spheres of influence. Therefore on the opposite to the Western perception, "For Russian leaders, soft power is instead a nonmilitary instrument for imposing its own goals and has always been perceived as a means of supplementing military power and contributing to manipulating, undermining, and weakening the opponent" (p. 4). Russia uses these means in offensive, deceitful and manipulative manner under the hybrid warfare strategy because of its victimized self-perception of failed superpower:

The Kremlin's especially broad sense of quite what constitutes 'war,' for example, the very measures imposed by the West in order to try and bring home condemnation of Russian aggression, economic sanctions, are themselves considered unilaterally hostile acts... Hence the belief that gibridnayavoina is quintessentially American invention...not only contributes to a sense of being under constant threat - and from a covert and subtle threat that could be behind any reversal, from labour unrest to lost trade opportunities - it also provides a justification for Russia's own 'guerilla geopolitics'... (Galeotti, 2016, p. 39).

\section{HYBRID WARFARE}

"Hybrid warfare, hybrid threats, and hybrid aggression have been concepts used to describe the unprecedentedly complex and tailored integration of a whole-of-spectrum approach to warfare in the 21st century" (Abott, 2016, p. 4). In the context of Crimean annexation, the debates over the definition of the concept of 'hybrid warfare' and more specifically its understanding as a new way of waging war by Russia have arisen. For this reason, it is necessary to define its meaning and take a closer look on debates encompassing it.

Scholars agree that hybrid warfare is neither an entirely new phenomenon nor that it can be attributed exclusively to Russian actions in Crimea and Ukraine in general. What is also acknowledged by many military analysts is that "... 
The beginning of the twenty-first century was marked by proliferation of hybrid wars, held between flexible and sophisticated adversaries engaged in asymmetric conflicts using various forms of warfare according to the purpose and timing" (Josan and Voicu, 2015, p. 49). The concept came to the light for the very first time in 2002 when William J. Nemeth used it to refer to the tactics of Chechen guerrilla against Russia during the Second Chechen War in 1999-2009. But the concept has become more popular among scholars after Frank Hoffman used it to describe the tactics of Hezbollah during the Lebanon war in 2006 which is assumed to be one of the most suitable examples of hybrid warfare. The level of complexity of actions performed by the non-state actor and its effectiveness was unprecedented. Drawing on the experience with Hezbollah's sophisticated and complex operations, the first theoretical basis for the concept of hybrid threats and warfare can be traced to Hoffman's Conflict in the $21^{\text {st }}$ Century published in 2007 where the author analysed the hybrid methods implemented by this nonstate actor as well as defended the novelty and uniqueness of the concept of hybrid warfare itself. Although there is no unified and mutually agreed definition within the academics, there are several characteristics upon which its advocates find consensus. In its broader sense the hybrid warfare can be characterized as difficulty in distinguishing between the state of peace and war as well as blurring warfare modes by simultaneously merging unconventional and conventional, irregular and regular, non-linear and linear, covert and overt methods of waging war by non-state actor or state, plus having attributes of being dynamic, flexible, unpredictable, subversive, complex and multidimensional. In the more narrow sense, Hoffman (2009) defines modern hybrid threats as following:

Hybrid threats incorporate a full range of modes of warfare, including conventional capabilities, irregular tactics and formations, terrorist acts that include indiscriminate violence and coercion, and criminal disorder. These multimodal activities can be conducted by separate units, or even by the same unit, but are generally operationally and tactically directed and coordinated within the main battlespace to achieve synergistic effects in the physical and psychological dimensions of conflict (p. 36).

Furthermore, he outlines four basic features of hybrid warfare: blended modalities of unconventional methods on the one side and conventional on the other side; simultaneity of warfare modes, fusion of professional army, guerrilla groups, terrorists and insurgents; criminality (Hoffman, n.d., as cited in Hashim, 2015 , p. 8). Another definition by Glenn (2009) proposes that hybrid threat is "An adversary that simultaneously and adaptively employs some combination of political, military, economic, social, and information means, and conventional, irregular, catastrophic, terrorism, and disruptive/criminal warfare methods. It 
may include a combination of state and non-state actors" (p. 2). The definition provided by European Parliamentary Research Service characterizes hybrid threat as "...a phenomenon resulting from convergence and interconnection of different elements, which together form a more complex and multidimensional threat" (Pawlak, 2015, p. 1). During the Wales Summit in 2014 NATO adopted definition of hybrid threat as consisting of "... wide range of overt and covert military, paramilitary, and civilian measures employed in a highly integrated design" (Kasapoglu, 2015, pp. 1-2). For the purposes of this paper the most accurate understanding of hybrid warfare will be a

...form of warfare that includes a range of multi-modal activities that can be conducted by state or non-state actors. Emphasis is placed on simultaneous and unprecedented fusion of a variety of means such as political, military, economic/ financial, social and informational using conventional, irregular, catastrophic, terrorist and disruptive/criminal methods to achieve political objectives. The hybrid actor fuses these means and methods in a way that is specific to and tailored-made to the context at hand (Abbott, 2016, p. 3).

However, the main dispute line among scholars rests in the controversy of novelty of the concept of hybrid warfare. Just as there are proponents advocating that hybrid war is a unique, distinct phenomenon that requires to be examined individually as a method of warfare, the opponents argue that there is nothing new about the concept of hybrid warfare since the multidimensionality of warfare methods and the interconnectedness of regular and irregular tactics was typical also for warfare further back in the history and in the most extreme case even doubt the existence of the concept itself. The main opponent of Hoffman is Thomas Huber who argues that hybrid warfare is nothing new, it has historically already been existing and the description provided by Hoffman is also suitable for defining compound warfare: "Huber contends that Hoffman's hybrid concept of the fusion of methods and modes of warfare is interesting and useful, but the dynamics he describes are not historically new and are simply insurgency" (Huber, 2009 as cited in Fleming, 2011, p. 15). Therefore the principal debate over the concept centres on whether compound and hybrid warfare are interchangeable concepts or whether they deserve to be approached respectively. Hoffman refuses to admit the blurring of these concepts, further explaining differences between them and broadening the definition of hybrid warfare. As opposed to hybrid warfare, in compound warfare the tactics of regular and irregular elements do not intersect and do not operate simultaneously, but rather the irregular elements serve the ends of regular ones by facilitating and enabling the creation of the space for actions and by helping regular forces to direct their efforts to ultimate victory: 
Compound wars offered synergy and combinations at the strategic level, but not the complexity, fusion, and simultaneity we anticipate at the operational and even tactical levels ...Irregular forces in cases of compound wars operated largely as a distraction or economy of force measure in a separate theatre... (Hoffman, 2009, p. 36).

However, in case of hybrid warfare the tactics of regular and irregular forces "...become blurred into one force in the same battle space, creating a layering of threats. The multi-modal activities used in hybrid warfare can be conducted by separate units or by the same unit - they do not have to be conducted solely by irregular forces" (Hoffman, 2007 as cited in Abbott, 2016, p. 7). In addition to this, what also makes hybrid warfare distinct from the compound one is the level of high-technological means it uses: "Although this type of warfare is not new, contemporary threat actors are redefining the application by employing $21^{\text {st }}$ century technologies and combinations of diplomatic, intelligence, militaristic, economic, informational, cyber and humanitarian means in all domains to create war on all fronts" (Morris, 2015, p. 2). Therefore because of these explanations, in this paper the concept of hybrid warfare will be approached respectively, as a unique concept existing on its own albeit not entirely novel, but taking into account its strategical, tactical and operational synergy as distinctive from the compound warfare.

\section{THE COMPONENTS OF HYBRID WARFARE}

Firstly, the cyber operations are nowadays becoming more and more prominent due to the contemporary unprecedented technological progress: "Cyberconflict' and 'cyber-war' serve as examples of the use of new technologies within the scope of hybrid threats. Cyber-war basically refers to a sustained computer-based cyber-attack by a state (or NSA) against the IT infrastructure of a target state" (Döge, 2010 as cited in Bachmann and Gunneriusson, 2015, p. 82). The cyber threat is potentially seriously destructive to state's security in particular if we consider the high level of dependence of state's defence, security and intelligence systems on computer technology and internet, having impact on command and control as well as leak of sensitive information. What makes cyber wars especially advantageous in comparison to other forms of warfare is that "...they offer varying degrees of covertness and their treatment under international law remains ambiguous" (Geers, 2015, p. 41). Depending on the intention, the level of covertness can vary from open attack to anonymous attack, the latter providing the opportunity for the attacker to refrain from being taken liable for the harmful cyber actions. In addition, its status under the international 
law is controversial, ambiguous and unresolved, so there is no legitimized counter reaction defined unless there was a serious harm done by this actions causing human casualties or damage of crucial infrastructure what could count as offensive action.

Secondly, the success of operations within the hybrid war substantially depends on the attitude of wider public and whether the challenger can attract it to his side: "The critical point is that to win hybrid wars, we have to succeed on three decisive battlegrounds: the conventional battleground; the conflict zone's indigenous population battle ground; and the home front and international community battleground" (McCuen, 2008, p. 107). To achieve these ends, the information warfare emerged as one of the most efficient tools of hybrid warfare with its main objective of influencing the attitude of population. In general, its aim is "...the dissemination of information to influence a target audience's values, belief system, perceptions, emotions, motivation, reasoning, and behaviour" (Svetoka, Reynolds and Curika, 2016, p. 17). Through the manipulation and influence of population, the challenger can affect the policies of government of the targeted state. The media and in particular social media and internet are especially helpful for the proliferation of propaganda due to their easy accessibility, rapid speed under which the information are spread, high amount of daily exchange of information and the unlimited reach: "The use of social media in this case would seek to achieve certain military effects in the cognitive domain - shape, inform, influence, manipulate, expose, diminish, promote, deceive, coerce, deter, mobilize, convince" (p. 17).

Thirdly, the cyber and information operations can be considered as part of broader psychological operations ${ }^{2}$. These encompass various deterring and offensive psychological methods in order to "...erode the fighting will and capability of enemy deployed forces and to induce their surrender, desertion, and defection; to deceive enemy leaders about friendly operations; to bolster the motivation and morale of friendly troops; and to win or coerce support from local populations" (Hosmer, n.d., p. 218). Apart from propaganda, the examples of such psychological tools can be the demonstration of military power, the build-up of troops at the proximity of borders, military exercises and simulations, military parades, attempts to undermine the legitimacy of government... On the one side, they are "...used to demoralize, disorient, and confuse hostile groups. Against such groups, psyops [psychological operations] are employed as an offensive weapon...", whereas on the other side "They can also be used, however, to unite, inform, and bolster the morale of nonhostile groups. When targeting neutral

${ }^{2}$ The definitions of the concepts of cyber, electronic, informational and psychological operations vary and blur therefore for the purposes of this thesis I will operate with the concepts respectively as defined above 
or friendly groups, they are used to support military objectives by developing cooperative attitudes... (Paddock, 1990, p. 19).

Fourthly "The advanced hybrid war can be defined also as a 'multilayered espionage' including intelligence and political-active operations combined with traditional and modern more technically executed espionage" (Rusi, 2015, p. 13). The possible intelligence operations include covert political operations with subversive effects to hostile country and on the contrary the operations supporting the affiliation towards the regime of the challenger, sponsoring political protests, stealing and misuse of confidential information, use of intelligence and special units, infiltration of the agents to the state structures of the targeted country with the intention to influence its policy outputs, political and ideological orientation...

Fifthly, another dimension of hybrid warfare is economic warfare: "Economic warfare (including specific economic sanctions) is intended primarily to influence economic, technology and military power balances to the advantage of the country/alliance conducting it" (Davis, 2016). Among its instruments can be assigned the freezing of bank accounts, the ban on imports and/or exports as well as on loans for banks and companies, restricted traveling, measures causing the decrease in production and investments, power cuts, the disruption of (industrial) infrastructure and other forms of economic blackmailing and intimidation. In addition, one of the most influential means of economic warfare are those linked to energetic sector "... one of the key tools for the creation of a 'hybrid war' is the energy component" (Slobodian, 2016). This most often means taking advantage of targeted state's vulnerabilities in terms of the lack of its own natural resources and its dependency on other state's natural and energy resources.

\section{GERASIMOV'S ARTICLE}

The introduction of Gerasimov's article ${ }^{3}$ begins by acknowledging the emergence of the new trend of war waging characteristic for the $21^{\text {st }}$ century. Even though the introduction outlines this shift as generally applicable, what is noticeable by further reading throughout the article is that Gerasimov continues to broaden this view only in relation to US and explicitly referring to its foreign policy which is interpreted as threatening Russian interests globally. As explanations are used colour revolutions that have occurred in the northern Africa and the Middle East which are mentioned, rather than addressing the contemporary warfare style in a broader understanding or providing other distinct examples. Although Russian military elite refuses to admit that the concept of hybrid warfare is existing in ${ }^{3}$ Since the original was published in Russian language and there is no official governmental translation available in English, I used the most credible translation published by Robert Coalson, the editor in Huffington Post journal and Radio Free Europe writer 
its military strategy - "Russian officials are emphatic that 'hybrid warfare' is not a Russian concept, but a Western one, indeed that is something that the West is currently waging on Russia" (Monaghan, 2016, p. 67) - there are irrefutable clues that the concept of 'gibridnayavoina' (as translated to Russian) is actually existing in Russian strategic military documents. Still, the article resembles the traditional Cold-war narrative where Russian identity in foreign and security policy is almost exclusively determined and threatened by the actions of the USA, NATO, EU and their foreign involvement.

In the first part is especially highlighted the Arab Spring which is in the article approached as a source of knowledge for Russian military elites, the lessons learnt, providing the guide on what to expect from military operations of the $21^{\text {st }}$ century, but also how to wage them. Covertness is the first feature from which the lessons should be learnt:

...it would be easiest of all to say that the events of the 'Arab Spring' are not war and so there are no lessons for us - military men - to learn. But maybe the opposite is true - that precisely these events are typical of warfare in the $21 \mathrm{st}$ century. In terms of the scale of the casualties and destruction - the catastrophic social, economic, and political consequences - such new-type conflicts are comparable with the consequences of any real war (Gerasimov, 2013 as cited in Coalson, 2014, para. 12-13).

What Gerasimov next deals with is multidimensionality and subversion: "The focus of applied methods of conflict has altered in the direction of the broad use of political, economic, informational, humanitarian and other nonmilitary measures - applied in coordination with the protest potential of the population" (Gerasimov, 2013 as cited in Coalson, 2014, para. 15). By this he recognized that modern warfare requires layering of various threats, total war, and the important role population plays in destabilization of enemy's internal order, cohesion of its essential institutions and therefore its defeat from inside. In relation to this he highlighted that nowadays it is crucial “...to be capable of defending one's population, objects, and communications from the activity of special operations forces, in view of their increasing use" (para. 41) but also mentioned "...the importance of creating a system of armed defense of the interests of the state outside the borders of its territory" (para. 35).

Another sign of hybrid warfare that can be found in the article is the blurring of conventional means and unconventional means: “...All this is supplemented by military means of a concealed character, including carrying out actions of informational conflict and the actions of special operations forces" (Gerasimov 2013 as cited in Coalson, 2014, para. 16). This means that there is still need to engage conventional military capabilities, but contemporarily the scope 
of their deployment is more limited than before and rather supplemented by unconventional means with special emphasis on covert information and intelligence elements, which are starting to take leading role in warfare: "The information space opens wide asymmetrical possibilities for reducing the fighting potential of the enemy...It is necessary to perfect activities in the information space, including the defense of our own object" (para. 34).

Modern military operations have to operate with increased flexibility and dynamics in order to promptly respond to threats of new security environment: "Military actions are becoming more dynamic, active, and fruitful" (Gerasimov 2013 as cited in Coalson, 2014, para. 18). Additionally, Gerasimov advances with pointing out the reinforced synergy of levels of military actions: "The defeat of the enemy's objects is conducted throughout the entire depth of his territory. The differences between strategic, operational, and tactical levels, as well as between offensive and defensive operations, are being erased" (para. 19). This eventually leads to intersection of forces, which are operating as united force in single battlefield: "The role of mobile, mixed-type groups of forces, acting in a single intelligence-information space because of the use of the new possibilities of command-and-control systems has been strengthened" (para. 18). All of this is enabled by technological progress: "New information technologies have enabled significant reductions in the spatial, temporal, and informational gaps between forces and control organs" (para. 18). In the end, according to Gerasimov, the ultimate objective of military operations nowadays is "...to create a permanently operating front through the entire territory of the enemy state" (para. 20).

The following parts of the article are dedicated directly and explicitly to Russian military strategy. Here Gerasimov sums up the previously gained experiences from waging wars in Afghanistan, North Caucasus and even the World War 2, describes its current state and necessity of future improvements. There are in particular three vital points relevant for this thesis that can be derived and which additionally confirm that the hybrid warfare is not a mere myth in Russian military thinking.

Firstly, he suggests that "...no matter what forces the enemy has, no matter how well-developed his forces and means of armed conflict may be, forms and methods for overcoming them can be found" (Gerasimov, 2013 as cited in Coalson, 2014, para. 55). This part seemingly refers to the awareness of technological superiority of the US and NATO forces over the Russian forces. Additionally, "...it is necessary to rethink the content of the strategic activities of the Armed Forces of the Russian Federation" (para. 31). Gerasimov criticized the lack of innovative thoughts in Russian military as compared to the World War 2 and emphasized the necessity of new ideas. This statement basically urges 
the change in Russian military thinking and war waging towards updating at that time contemporary warfare to a more inventive one.

Secondly, another advice that is provided by Gerasimov affirms the importance of context and uniqueness of circumstances that need to be taken into account when considering waging war which also falls under the basic features of hybrid warfare: "...each war does present itself as a unique case, demanding the comprehension of its particular logic, its uniqueness. That is why the character of a war that Russia or its allies might be drawn into is very hard to predict" (Gerasimov, 2013 as cited in Coalson, 2014, para. 58).

Lastly, further examining the article it becomes evident that this new military thinking is of offensive nature rather than defensive: "We must not copy foreign experience and chase after leading countries, but we must outstrip them and occupy leading positions ourselves" (Gerasimov, 2013, as cited in Coalson, 2104, para. 56).

\section{HYBRID WARFARE IN CRIMEA}

This section will apply the theory of hybrid warfare, especially its main features, on case study of Crimea. Step by step, following characteristics of hybrid warfare will be displayed on this case: firstly, specificities and uniqueness of circumstances will be explained through outlining the relation between the main actors - Russia and Ukraine (and Crimea) by using Lanoszka's assumptions that explain why post-Soviet regions are ideal theatre for hybrid warfare. Next, the analysis of the context that contributed to the effectiveness of Russian hybrid war will be presented. Then, the application of concrete unconventional and conventional means of hybrid warfare will be demonstrated on Crimean operation.

\section{THE SPECIFICITY AND UNIQUENESS OF CIRCUMSTANCES}

One of the attributes of hybrid warfare is that, just like in any other war, one need to take into consideration specificities, uniqueness and tailor-made approach to each case respectively against which the war is waged. These specificities are important for deciding on the employed character of hybrid operations and selection of hybrid means. Ukraine is undoubtedly a very specific case and several specific factors enabled effective hybrid warfare in order to achieve the political end - the annexation of Crimea and therefore the demonstration of great Russia revival. 
As first, Lanoszka names ethnic Russian minorities to be one of the decisive factors that attract Russian hybrid warfare. In case of Russia and Ukraine, the matter of ethnicity is indeed the most relevant for explaining contemporary situation. The NSS deals with this issue the most profoundly. It recognizes other cultures within the Russian federation:

The foundation of the common Russian identity of the Russian Federation's peoples is the historically evolved system of unified spiritual moral and cultural historical values, as well as the distinctive cultures of the Russian Federation's multinational people as an inalienable part of Russian culture (National Security Strategy, art. 4, para. 77).

However, despite being federation compounded of numerous nations, as strategic objective in terms of culture is principally defined the promotion of traditional Russian values and culture without mentioning the support for other distinctive cultures: "...the preservation and augmentation of traditional Russian spiritual and moral values as the foundation of Russian society..." (Russian National Security Strategy, art. 4, para. 76a), "the preservation and development of the common Russian identity of the Russian Federation's peoples and of the country's unified cultural area" (para. 76b), “...realizing the function of the Russian language as the state language of the Russian Federation, a means of ensuring the country's state integrity and interethnic communication among the Russian Federation's peoples, the basis of the development of integration processes in the post-Soviet area" (para. 81). This perception of Russian nation as superior and leading is projected also in its foreign policy in relation to its citizens abroad but also in relation to other nations with the objectives of: "ensuring comprehensive protection of rights and legitimate interests of Russian citizens and compatriots residing abroad, and promoting, in various international formats, Russia's approach to human rights issues" (Concept of the Foreign Policy of the Russian Federation, art.1 para. 4g), "...disseminating information on the achievements of the peoples of Russia and consolidating the Russian diaspora abroad" (art.1, para. 4h), "expanding and strengthening the space of the Russian language and culture" (art. 2, para. 39d), "strengthening the position of the Russian language in the world, and developing a network of Russian scientific and cultural centers abroad" (art. 5, para. 100), to "improve the level of protection of rights and legitimate interests of Russian children living abroad" (art. 3, para. 39m) or even "promoting interstate cultural and humanitarian relations between Slavic peoples" (art. 2, para. 39g). The language used in these documents is rather of offensive and expansionist nature than of defensive, moreover the statements like upholding of 'Russia's approach to human rights issues', 'unified cultural area', 'integration processes in the post-Soviet area' or specifically highlighted 
ethnicity - the Slavs - to enhance cooperation with encourages the perception that Russia seeks to revive its historical greatness. This impression is even strengthened by the amended law on defence from 2009 that enables Russian armed forces to intervene abroad - apart from other - for the reason "to protect Russian citizens abroad from armed attack" (Dmitry Medvedev signed the Federal Law, 2009) which is in contrary to international law.

Applied on case of Ukraine, the State Statistics Committee of Ukraine (AllUkrainian population census 2001, 2003-2004) suggests, that according to the latest census of Ukrainian population conducted in 2001, there are 8,334,100 of Russian nationals ${ }^{4}$ inhabiting Ukraine, measured in percentage terms $17.3 \%$, of the entire Ukrainian population what represents the largest diaspora of Russian population abroad. From this number, 95.9\% of Russians consider Russian language to be their primary language and only $3.9 \%$ of these Russians approach Ukrainian language as their mother tongue. The Autonomous Republic of Crimea inhabits $1,180,400$ of Russians which is in total $58.5 \%$ of total population of Crimea. The number of Russians in Crimea exceeds other nationalities inhabiting the peninsula. These demographic statistics make especially favourable conditions for Russia to be taken advantage of.

Secondly, historical grievances are substantial as well. Some of the sources of grievances that emerged throughout the history between Russia and Ukraine and are relevant for contemporary situation are those related to common ethnicity for example, Western historians agree that Russians, Belarusians and Ukrainians "...share a common origin and only began to diverge ethnically following the Mongol invasions... This is also the view of most Russian historians. Ukrainian historians, however, believe that Ukrainians and Russians have distinct origin..." (Tismaneanu, 1995, pp. 177-178). Another example is the interpretation of the Treaty of Pereyeslav - the agreement served to Russia as a justification for fullscale merging of Ukraine into the Empire:

One of the most controversial topics in current Russo-Ukrainian discussions on the legacy of Pereyaslav has been the usage of the term 'reunification'. Ukrainian historiography has effectively rejected the old Soviet cliche of the Pereyaslav Agreement as a reunification of Russia and Ukraine... (Plokhy, 2001, p. 491).

As far as the agreement is mentioned, in 1954 the Crimean peninsula was transferred by then head of the Soviet Union, Nikita Krushchev to Ukraine as a gift to celebrate the three hundred years' anniversary of the Treaty of Pereyaslav:

\footnotetext{
${ }^{4}$ Nationality was identified based on expressed affiliation of respondents, in case of juveniles the nationality was identified by parents and where controversial, nationality was defined by the nationality of mother
} 
The transfer of the Crimea to the Ukraine is in the interpretation of the Communist Party a gift of the "elder brother" to the "younger brother" on the occasion of the tricentennial of the unification of Russia and the Ukraine, as if to demonstrate the solicitude of the central government and its desire to meet the Ukrainian people halfway, at the same time reducing its gravitation toward independence from the Kremlin (The Transfer of the Crimea to the Ukraine, 2005, para. 10).

This act has later become the root of disagreement between both countries due to the question of the legacy of the transfer. As it can be seen the interpretation of certain historical realities still drives current foreign and security policy of Russia.

Thirdly, the civil societies of post-Soviet countries are generally labelled as weak. In case of Ukraine, this Lanozska's assumption is relative. On the one hand, in terms of civilian activity versus passiveness to public affairs, Euromaidan 2013 is considered to be a turning point, the civic awakening and the most massive mobilization of civil society in post-Soviet Ukraine:

Euromaidan has brought about a decisive break with the typical 'postSoviet' model of civil society...Overall, post-Soviet societies were generally characterised by apathy, low social capital (meaning the quality and density of social networks and interactions beyond one's immediate family and friends) and profound mistrust of all public institutions. Euromaidan has led to a number of qualitative changes that include the emergence of new actors and new patterns of social organisation, a rise in social capital and a change in attitude of the society towards the state (Pishchikova and Ogryzko, 2014, p. 6).

However, on the other side, in terms of cohesiveness of population, the disunity of population over the inclination of the country towards the West or the East significantly deepened its fragmentation. On 6 March 2014, therefore shortly before the annexation of Crimea occurred, a survey conducted by SOCIS, a political sociology company in Ukraine showed, that 80 percent of population would vote in the potential referendum and "Among those who said they would vote in a referendum, the distribution amounted to 62 percent choosing the EU and another 38 percent favoring the Moscow-led alliance" (The Moscow Times, 2014, para. 4). According to another survey conducted by the International Republican Institute, when in February 2014 asked 'If Ukraine was able to enter only one international economic union, should it be with...?', $41 \%$ of Ukrainian population would vote for joining the EU whereas $36 \%$ would vote for joining Customs Union with Russia, Belarus and Kazachstan (Public Opinion Survey Residents of Ukraine, 2014, p. 11). The rise of para-military and separatist radical violent organisations contributed to further fragmentation 
of the Ukrainian population. It is this fragmentation that makes Ukraine an easy target for hybrid warfare despite the increased civic engagement in public affairs that was sparked by Euromaidan.

Fourthly, the complexity of post-Soviet region is advantageous for Russia mainly due to economic and energy dependence these countries have towards Russia:

This dependence makes neighbouring countries vulnerable if Russia decides to employ economic or energy instruments in pursuit of its goals. Moreover, close economic ties provide Russia with additional channels of influence in these countries, via corrupted politicians, business partners, and companies owned by Russian citizens (Šešelgyte, 2014, para. 4).

Russia is Ukraine's biggest trading partner: “...most of Ukraine's import and export business is carried out with its eastern neighbor" (Statistics and facts on Ukraine, n.d.) what according to statistics makes $12.71 \%$ of its export and $20.07 \%$ of import distribution (Ukraine: Trade Statistics 2015). As far as energy imports are concerned, Russia and Ukraine share a history of serious disputes over the supply of gas and its redistribution to Europe through Ukraine what even led to cut off supplies from Russia. Prior the current crisis with Russia “... Ukraine was dependent on external energy sources, mainly from Russia. In 20112013, Ukraine imported from Russia up to $92 \%$ of its gas supply, up to $100 \%$ of nuclear fuel, up to $40 \%$ of oil products" (Pavlenko, 2016). After the crisis Ukraine is reducing its dependence on Russia by diversifying import partners in order to prevent Russia from exploiting former dependence vulnerability for the purposes of hybrid warfare.

\section{THE IMPORTANCE OF CONTEXT}

When explaining the importance of context and how it enabled Russia to wage successful and efficient hybrid war, we need to examine the most dominant aspect - the integration efforts towards the Western structures. Observing the context will help us to understand how Russia took advantage in available context and applied the above mentioned specificities in it for the purposes of hybrid warfare.

Lyubashenko-Zasztowt suggests that "Ukraine has balanced between EuroAtlantic integration and closer cooperation with Russia both on a declarative and practical level" (2012). The relations between NATO and Ukraine reached its peak at the Bucharest Summit in 2008 when the agreement on Ukraine's accession to NATO was made: "NATO welcomes Ukraine's and Georgia's Euro-Atlantic aspirations for membership in NATO. We agreed today that these 
countries will become members of NATO" (Bucharest Summit Declaration, 2008, para. 23). The affiliation of Ukraine toward NATO was met with the resistance of Russia: Ukraine's potential admission as a member of the alliance was unthinkable to Moscow, given the economic, cultural and ethnic ties that run deep into the history of the two states. Russia was also alarmed by the possibility that Ukraine may host BMD components on its territory. Putin made it clear... that under such conditions, Russia would target Ukraine's missile components (Lilly, 2014, p. 193).

The same applied in case of integration with the EU. Yanukovych in the law On the Foundations of Internal and Foreign Policy 2010 specified in the article 11 orientation of Ukraine towards the EU: “...ensuring the integration of Ukraine into the European political, economic and legal area in order to obtain the EU membership" (Ukraine-EU Relations, 2012, para. 2). However, on 28-29 November 2013 Vilnius Summit, former Ukrainian President Viktor Yanukovych facing the pressures from Russian side rejected the signing of the Association Agreement between the European Union and the European Atomic Energy Community and their member states, of the one part, and Ukraine, of the other part and Deep and Comprehensive Free Trade Area with the European Union. The character of this document was unprecedented due to the fact that its signing would represent a breaking point, the decision on future direction of Ukraine towards the EU rather than Russia. It was the first document of such nature to be signed by the country of Eastern Partnership and the tightest link to EU any other Eastern Partnership country had ever established. However, as an alternative was offered a $\$ 15 \mathrm{bn}$ aid package from Russia in order to restore Ukraine's economic growth and the offer also contained significantly lower price for the delivery of Russian gas, from the original $\$ 268$ per 1,000 cubic metres to $\$ 400$ per the same amount (Walker, 2013). The withdrawal of Yanukovych from the deal with the EU resulted in Ukrainian civil revolution on 18-23 February 2014, ouster of Yanukovych and his replacement by pro-EU and pro-NATO oriented President Petro Poroshenko. On 18 March 2014 Crimea was annexed by Russia as a reaction to the changing situation.

\section{MULTIMODALITY AND BLENDING OF CONVENTIONAL AND UNCONVENTIONAL METHODS}

This part of the paper will deal with the Crimean operation and the effective layering of conventional and unconventional threats which was conducted upon it as part of Russian hybrid warfare in Ukraine. Most important of them will be demonstrated in the sections below. 


\section{INFORMATION MEANS}

Information warfare as a part of wider Russian hybrid war is certainly a cornerstone of its operations: "The Kremlin has been implementing a novel strategic approach in Ukraine since at least February 2014 that depends heavily on Russia's concept of "information warfare"" (Snegovaya, 2015). The most important feature of information warfare that enabled the annexation of Crimea is Russia's reflexive control through the substantial Russian speaking minority and sympathizers on the peninsula. The objective of Russian information warfare in Crimea was to in secrecy deceive, confuse, convince and attract Russian speaking minority (which in fact forms a majority of peninsula's population) inhabiting the peninsula without any resistance or use of force by employing the manipulation of information in such a way that is beneficial for Russia's political objectives, in this case to evoke the rise of pro-Russian sentiments and through this to legitimize its illegal actions - the annexation of territory. In practice, Crimea was illegally annexed and this act was seemingly legitimized by the Crimean so-called 'referendum' ${ }^{5}$ for which ends was the misinformed majoritarian Russian speaking population of the peninsula misused:

The Crimean operation perfectly shows the essence of information warfare: the victim of the aggression - as was the case with Crimea - does not resist it. This happened because Russian-speaking citizens of Ukraine who had undergone necessary psychological and informational treatment (intoxication) took part in the separatist coup and the annexation of Crimea by Russia (Darczewska, 2014, p. 83).

The fact that Russian speaking minority in Crimea represents in overall 58.5\% of the total population of Crimea made the likelihood of operation's success and effectiveness even higher when we consider the potential of the misuse of this statistics: "The Russian-speaking diaspora, who have maintained cultural and emotional bonds with Russia, was Russia's main ally during the Crimean operation" (Darczewska, 2014, p. 34). The results of this so-called 'referendum' were part of disinformation propaganda under the hybrid war: "The Crimean

\footnotetext{
${ }^{5}$ Under the Resolution 68/262 adopted by the UN General Assembly on 27 March 2014, the Crimean status referendum was declared illegal. Holding the 'referendum' contradicted with the Ukrainian constitution and did not meet the basic internationally agreed standards institutionalized in the Code of Good Practice on Referendums - freedom, secrecy, equality as well as universality of election. There was a military presence of Russian and pro-Russian soldiers having control over public infrastructure, the neutrality of public authorities was not guaranteed, the provision of clear and non-misleading referendum question was not fulfilled, there was a non-existence of law regulating the 'referendum', not all stakeholders were involved in the voting and also, there was a presence of external observers whose affiliation status was mostly unknown (Marxsen, 2014, pp. 380-382).
} 
vote was superficially successful with reportedly 97 percent of the population voting to secede on an 80 percent turnout. In fact...turnout was only 30 percent, half of whom voted against independence..." (Murphy, 2016, para. 38). This was one of the most dangerous examples of how Russia misused the high percentage of its misinformed ethnic minority in Crimea for its political objectives. Moreover, the survey of International Republican Institute found out that 49\% of ethnic Russians definitely did not perceive Russian-speaking citizens to be under the threat due to their language in contrast to $12 \%$ of the same group that definitely felt that Russian-speaking citizens were under the threat due to their language (Public Opinion Survey Residents of Ukraine, 2014, p. 5). The same institute conducted a survey in May 2013 concerning the preferred affiliation of the residents of Crimea. Even though 53\% of them preferred Customs Union over the EU that was favoured by $17 \%$ (Public Opinion Survey Residents of the Autonomous Republic of Crimea, 2013, p. 14), only 23\% agreed that Crimea should be separated and given to Russia, whereas 53\% supported its autonomy within Ukraine (p. 17). In addition, when surveyed about the same question, 58\% of population of Eastern Ukraine shared the view that Russian-speaking citizens are definitely not oppressed due to their language in contrast to $5 \%$ population of Eastern Ukraine who thought exactly the opposite (p. 6). Apart from this case, the information warfare on Crimea employed also the form of media censorship. Prevalent number of Ukrainian TV channels was replaced by the Russian ones: "Since Russian troops have moved into Crimea, most Ukrainian channels have been blocked and have been replaced with Russian channels" (Jovanovski, 2014, para. 20). Moreover, Giles (2016) further adds that:

Russia also successfully achieved control over telecommunications including the notionally independent internet, and thus successfully isolated Crimea from independent news from the outside world. The result was public perception in Crimea of events in the rest of Ukraine being determined exclusively by Russia, which greatly facilitated the Russian seizure of the peninsula and subsequent attempts at its legitimation (p. 10).

Another example is the usage of Kremlin-paid pro-Russian trolls and agitators that spread disinformation on blogs, websites or social media, mainly on public discussions. Some of the most generally known spread disinformation about Crimea are those that claim that Crimea has always been Russian - as also the Ministry of Defence of Russia through its official website announced that Crimea belonged to Russia as far as 160 million year ago (TV Channel of RU Ministry of Defence, 2016), that the Russian minorities in Crimea need to be protected by Russia from the Kyiv's extremists and oppressive nationalists (Putin: Russia Could Not 'Abandon' Crimea, 2015), that Crimea was not annexed but actually 
re-unified (Putin Says Crimea Not Annexed, 2015; 2 Years on Almost All Russian Support Reunification, 2016). These actions had also further reaching goals than annexation of Crimea which was only the demonstration of hybrid warfare on operational level. Russia conducts hybrid warfare also on tactical and strategic levels - it also targets the rest of Ukraine, USA and NATO. For example, some of the spread disinformation were that US-led NATO was intending to set up a military base on the peninsula against Russia (US Plays Double With Russia After Plans for Base in Crimea Failed - Experts, 2015), that USA and NATO hacked the website of Crimean referendum (Crimean Govt: Referendum Website Downed by Cyber-Attack From US, 2014) or that the peninsula was under the threat of Fascism/Nazism from Ukrainian government because the government there consists of the Fascists/Nazis (Democratic Vote, Govt Without Fascists Needed in Ukraine, 2014). The propaganda projected from Crimean operation goes even that far that it suggests that the treaties can be made retroactively void as was the case with Khrushchev's gifting of Ukraine with Crimea (New Russian Bill Condemns 1954 Transfer of Crimea, 2015; Russian Bill Seeks To Nullify Crimea's Soviet-Era Transfer, 2014) or it even provides alternative reality: "Ukraine has never existed in history, goes the claim, or if it has, only as part of a Russian empire. Ukrainians do not exist as a people; at most they are Little Russians” (Snyder, 2014, para. 2).

\section{ATTACKS ON CYBER INFRASTRUCTURE}

Even though the cyber warfare was not used by Russia during the Crimean operation in such a great scope as the information warfare, several examples of attacks on cyber infrastructure can be traced during this operation. Ukrtelecom, the Ukrainian National Telecommunications Operator, complained in February 2015 that two armed men invaded its office branch in Simferopol and physically disconnected cables providing the connection between the peninsula and the mainland (Ukrtelecom shuts down communication services in Crimea, 2015). Other reports on interference with telecommunication technology in Crimea informed that: "In early March, Ukrtelecom reported kinetically damaged fiberoptic trunk cables, as well as the temporary seizure of its company's offices" (Maurer and Janz, 2014 as cited in Jaitner and Mattsson, 2015, p. 45). Moreover "Further disclosures detailed the jamming of Ukrainian naval communications. SBU Chief ValentynNalyvaichenko declared that Ukrainian government officials' mobile communications were subjected to an 'IP-telephonic attack" (Paganini, 2014 as cited in Jaitner and Mattsson, 2015, p. 45). These attacks performed on the Ukrainian state representatives were directed from seized Crimea: "Ukraine's 
mobile phone infrastructure is under a massive attack originated in Crimea that is interfering with the phones of members of parliament" (Paganini, 2014, para. 4). Paganini further explains that "The attackers used equipment installed within Ukrtelecom networks in the Crimea region under the control of Russian forces" (para. 12).

As it could have been seen, Crimean cyber operations were part of broader cyber warfare targeting also Ukraine. Moreover, the reports from the American FireEye firm specialising in malware research state that after the annexation of Crimea it “...tracks more than 30 million 'callbacks,' the messages sent back from infected computers, allowing hackers to control them remotely. In March of 2014, callbacks to Russia jumped by 40 percent..." (Brandom, 2014, para. 2). Plus, according to Ukrainian President, from October to December 2016 "Hackers have targeted Ukrainian state institutions about 6,500 times..." (Zinets, 2016, para. 1).

Even NATO experienced cyber attacks on its website in March: "Hackers brought down several public NATO websites...in what appeared to be the latest escalation in cyberspace over growing tensions over Crimea" (Croft and Apps, 2014). According to the British Defence Secretary Michael Fallon "Russian hacking is being used to undermine democracy and destabilize the West and NATO" (Cuthbertson, 2017, para. 1).

\section{PSYCHOLOGICAL MEANS}

Information and cyber operations can be considered as subparts of psychological operations under the Russian hybrid warfare. Russian psychological operations are especially aimed at on the one hand delegitimizing and intimidating the opponent and on the other hand perfecting the image of Russia in the eyes of domestic and foreign public and legitimizing its actions. Most of the psychological operations were conducted through media.

Probably the best example of psychological operations in Crimea was the effort to legitimize Russian invasion of Crimea by delegitimizing Ukrainian government through evoking fear as a political tool. The psychological operations used the myth of fascism that according to Putin was seriously threatening Crimea: "A Western-sponsored fascist junta had seized power in Kiev and threatened Russian-speakers. Crimea was saved by prompt intervention, but the south and east of Ukraine fell into civil conflict" (Putin's Gambit, 2014, para. 4). The Russia's leader of Federal Agency for Nationality Affairs supported this narrative by fabricating that the existence of fascist government is real: "Almost half of Crimean Tatars (46\%) are opposed to Crimea's return to fascist Ukraine, 
whereas just $17 \%$ of them are pinning their hopes on Kiev" (Crimean Tatars Opposed To Crimea's Return To Fascist Ukraine, 2016, para. 1). By spreading intimidating information about fascist regime, Russian propaganda mutated, misused and exaggerated the concept of fascism and made parallels to Ukraine's historical pro-independence nationalist Stephan Bandera who cooperated with Hitler before declaring Ukrainian independence and transferred this reality on contemporary Ukrainian pro-independence radical nationalists in order to legitimize Crimean annexation after pro-Russian Yanukovych was ousted: "The self-defense teams which sprang up last spring to defend the peninsula from the imagined fascist threat continue to patrol Simferopol's streets, and many continue to credit Russia's President Vladimir Putin with saving Crimea's Russophonic population from genocide" (Luxmore, 2015, para. 3). By this misuse of the concept, Putin aware of losing his ally Yanukovych also recalled the historical fear of Nazis fighting in Crimean campaign during the Second World War in 1941 which was one of the greatest bloodshed on the Eastern front.

With this are also connected subversive efforts from Russia that pursue to undermine the legitimacy of Ukrainian government and the EU, NATO and the USA as its affiliates. Euromaidan and Ukrainian revolution are interpreted as illegitimate neo-Nazi revolts: "The Kremlin describes last month's uprising in next-door Ukraine as an illegitimate fascist coup. It says dark rightwing forces have taken over the government, forcing Moscow to 'protect' Ukraine's ethnic Russian minority" (Harding, 2014, para. 3). The pro-Russian propaganda is then spreading disinformation that Europe is collaborating with these fascists by supporting their regime: "This is the first time since the Second World War that a European government has been penetrated to such an extent by fascist influence...that armed neo-Nazis have been shamelessly deployed against their own population" (Ploeg, 2016, para. 23) or that “...the Ukraine crisis explains the nature of the Kiev proxy regime. We are dealing with a Neo-Nazi government supported by 'Western democracy' and the 'international community"' as suggests another pro-Russian propaganda website (Chossudovsky, 2016, para. 1). It is then understandable where the conspiracy theories on the EU, NATO and USA pro-fascist inclination came from. The combination of means together - the invention of a non-existent threat accompanied by the historical fear, restricted access to alternative media and information from the outer world and the seeming will to protect the citizens make Russian strategy especially dangerous and effective.

The next example of how Russia tries to intimidate its opponent is through demonstration of military power, most actually through Kavkaz exercise 2016 under the pseudonym "Crimea War Games" that takes place in Crimea and 
which Konashenkov, the spokesman of the Russian ministry of defence labelled as unprecedented: "On such a scale and with the deployment of different force groupings, such drills are being held for the first time" (Russian Ministry of Defence Releases Shocking Images of Crimea War Games, 2016). The further demonstrations of military power that is supposed to intimidate the rival not only on operational but also on tactical and strategic level are mainly joint exercises of Belarus and Russia which are very direct in their intention - the usual scenario is very similar to what happened in Crimean operation - Zapad 2009 scenario was a reaction on joint attack of Poland and Lithuania on Belarus where Lithuanian minorities were oppressed and Zapad 2013 exercise simulated an erosion of mutual relations between states as a result of inter-ethnic, ethnoreligions differences and claims on territory. Some examples of disinformation with demoralizing effects exaggerate the military superiority of Russia as certain tabloids announce: "NATO would lose World War 3 to Russian in less than three days, a US defence official has warned" (Trayner, 2016). Other disinformation rumour about NATO's future air blitzkrieg on Russia and the necessity of Russia to prepare for it (Vasilescu, 2016). Moreover, frequent are also provocations and incursions into NATO airspace, the concerns were raised especially by the Baltics States:

Nato fighters policing Baltic airspace were scrambled 68 times along Lithuania's borders this year, by far the highest count in more than 10 years. Latvia registered 150 'close incidents', cases where Russian aircraft were found approaching and observed for risky behaviour. Estonia said its sovereign airspace had been violated by Russian aircraft five times this year, nearing the total count of seven over the previous eight years (Milne, Jones and Hille, 2014).

Milne, Jones and Hille further add that "...other Nato members including Canada, the US, the Netherlands, Romania and the UK have experienced airspace infringements as well" (2014).

\section{INTELLIGENCE MEANS}

Russian security service, the FSB has as well been actively taking part in psychological and information operations of Russian hybrid warfare. The FSB was and continues to be active in Crimea mainly in persecution of dissidents of the regime. The new Criminal Code of Russian Federation was updated and broadened by new legislation:

The Russian parliament's lower house approved amendments that would see all public incitement to separatism penalized. Violation of the law through the media or the Internet will now be punishable by up to five years in prison. Calls 
to separatism made without the use of the media or the Internet are punishable by four years in prison (Russia Broadens Anti-incitement Law, 2014, para. 3-4).

Passing this law enabled Russia to persecute dissent population in Crimea either by the FSB itself or by information provided by its sympathisers, as one propaganda notice on house in Crimea states:

Although peace has been established in our land, there still are scums who want chaos, disorder, and war. They live among us, go to the same shops as we do, ride with us in public transport. You may know the people who were against the return of Crimea to the Russian Federation or took part in the regional 'Maidan'. Such personalities should be reported immediately to the FSB at: 13, Franko Boulevard, Simferopol, or by phone... (Zayets et al., 2015, p. 33).

Several examples of this persecution by the FSB can be traced in Crimea. In March 2014 The Committee to Protect Journalists informed that

In two separate raids today in Crimea, FSB agents searched the homes of the parents of journalists Natalya Kokorina and Anna Andriyevskaya, according to news reports...Andriyevskaya told journalists that FSB agents showed her parents documents that said she faced anti-state charges in connection with an October 2014 article she wrote in which authorities said she called for the Russian regime to be overthrown in Crimea (Russian FSB Agents in Crimea, 2015, para. 3).

One of the latest examples are the FSB's claims that “...it prevented a sabotage attack plotted by Ukrainian military intelligence operatives in the southern Russian city of Sevastopol, targeting local infrastructure critical for the civilian population" as Russia Today, a news channel that is considered to be pro-Russian propaganda channel informed (Ukrainian Commandos Planning Attacks, 2016, para. 1). These detained persons are labelled as terrorists: "Russia's Federal Security Service (FSB) has prevented terrorist attacks in Crimea that were planned by the Ukrainian Defense Ministry's intelligence agency" (Russian FSB Foils Terrorist Attacks Plotted by Ukrainian Intel Agents in Crimea, 2016, para. 1). The FSB is then glorified as "anti-terrorism agency" fighting "Ukrainian saboteurs" (Mercouris, 2016) what seemingly legitimizes its actions and reprisals in the eyes of public. This type of operations have impact not only on operational but also strategic level: "Russian observers claim that Ukraine is trying to destabilize the situation in Crimea and thus attract the West's attention to the peninsula" (Timofeychev, 2016, para. 1). This projection to the strategic level is evident also on the example of another Russian propaganda website that claims that:

A Russian soldier and a Federal State Security (FSB) agent were killed during these [sabotaging] actions. Russians call the attackers 'terrorists'...The events 
in and around Crimea must be seen in the context of the ongoing, multilayered campaign by Washington and its junior partners in the NATO military alliance to whip up war fever against Russia (Butterfield, 2016, para. 2-3).

\section{MILITARY MEANS}

In a trailer for a documentary due to air on Russia's state television channel Rossiya-1, President Putin admits that on the night of 22 February ${ }^{6}$ he told his colleagues to 'start the work' on returning Crimea to Russia...It was four days after this meeting that unidentified armed soldiers, dubbed 'little green men', appeared in Crimea, raising the Russian flag after taking hold of the local government buildings (Eleftheriou-Smith, 2015).

"The Crimean operation, although most probably conducted according to existing contingency plans, was sudden and executed mostly without direct fighting" (Bukkvoll, 2016, p. 16). However, the presence of conventional military means also cannot be refuted in case of Crimean operation. In February 2014 , the presence of armed men dressed in military camouflage was spotted in Crimea. Since these men lacked any visible insignia that could enable identifying them, Crimean population nicknamed them as the 'little green men' or also as the 'polite people': "In 2015, Russian president Vladimir Putin, in a series of interviews and films about so-called 'Crimean spring', finally admitted that the 'little green men' were in fact Russian military soldiers (Zayets et al., 2016, p. 8). Even the pro-Russian Russia Today came with the information that "Russian President Vladimir Putin has acknowledged that Russian troops were present in Crimea before the so-called 'referendum' and argued that was necessary to let Crimeans make the choice on the future of the region" (Putin Acknowledges Russian Military Serviceman Were in Crimea, 2014, para. 1). The Russian government's official TV further continued that Putin proclaimed that "Crimean self-defense forces were of course backed by Russian servicemen" (para. 3). All of this was done under "...speed and surprise to establish fait accompli on the ground, thus making a military response from the Ukrainian side difficult" (Bukkvoll, 2014, p. 21). On February 27 the parliament of the Autonomous Republic of Crimea and the Council of Ministers in Simferopol was seized by these armed men while hoisting the Russian flag on governmental buildings. On the next day "Masked men toting Kalashnikovs had set up a makeshift border and began checking vehicles, as Russian flags flapped in the late-winter wind" (Sonne, 2014, para. 3).

${ }^{6}$ Therefore the plan was launched as soon as three weeks before the so-called referendum on the status of Crimea was held (16 March 2014). 
As far as the special operation units - the Spetsnaz - are involved, it is hard to determine their role in Crimean operation, since the sources of information are obviously not available and even pro-Russian media omit mentioning them. However, Russian military experts Lavrov and Nikolsky (2014 as cited in Bukkvoll, 2014 p. 17) suggests that

...the take-over of Crimea was the first operation of a significant scale undertaken by the SOC. In particular, SOC was behind the seizing of the local parliament on September 27. This act made it possible to elect the Russian 'marionette' Sergei Aksenov as new Crimean prime minister. Furthermore, SOC also led the takeover of the Ukrainian military's headquarters and a number of other hard-target military compounds. These were, however, operations that demanded more troops than SOC could provide. The organization was therefore aided by units from Spetsnaz-GRU and naval infantry. The SOC, however, was always in the lead...

On tactical and strategic level, Russia Today turned the information warfare on special operation forces too. For example, it disinformed that "A Ukrainian Special Forces company dispatched in Ukraine's centermost major city of Kirovograd has disobeyed an order to march on to Crimea" (Ukrainian Special Forces Regiment Joins Other Units, 2014, para. 1) or as a reaction to the fact that the USA deployed its special operation unit for the exercise in Lithuania Russia used the offensive rhetoric that "...every sovereign right to take necessary measures throughout the territory of the Russian Federation" (Lithuania Confirms Presence of US Special Forces, 2017, para. 15).

\section{PARAMILITARY, TERRORISM, CRIMINAL, COERCIVE MEANS}

Unlawful coercive activities accompanied Russian operation in Crimea as well. As was already mentioned, some of the most occurring actions of this kind were illegal persecutions of journalists and their mistreatment. In the previous case of persecution of Crimean journalists by the FSB, victims witnessed to the Centre to Protect Journalists that "[Russian] Authorities [in Crimea] detained Kokorina and initially refused her access to her lawyer, the center said. Six hours after interrogating her, she was released, the center said" (Russian FSB Agents in Crimea, 2015, para. 3) The CPJ further claims that "Local and international journalists covering Crimea have been harassed, attacked, detained, and had their equipment seized..." (para. 5). Another reporter complained that "When he and two cameramen walked up to a Russian checkpoint in Ukraine, Ostrovsky says he and a colleague were grabbed and thrown to the ground by guards who 
seemed to be part of the disbanded Berkut special forces" (Jovanovski, 2014, para. 3). After the Ukrainian special police force Berkut was officially disbanded by the Ukrainian government due to its separatist and criminal activities, Russia took advantage in this situation and as its Ministry of Interior announced through the official channel "The Berkut officers who choose to get a Russian citizenship will be offered career opportunities in some regions of Russia" (Russia Starts Giving Out Passports, 2014, para. 3). According to Sridharan (2014) "The Russian foreign ministry said it has ordered its diplomatic mission in Crimea, the autonomous Russian-dominated region in Ukraine which is turning into a key battleground of the crisis, to issue passports and citizenship cards to Berkut personnel" (para. 2). This is another example how Russia misused pro-Russian Ukrainian population in its paramilitary operations on Crimea for broader political objectives. In addition to this, pro-Russian self-defence forces supported by Russia in Crimea were gradually emerging. For example, following the attempts to seize Ukrainian military base in Crimea in March 2014 some witnessed that "Armed pro-Russian paramilitaries in civilian clothing were still in the area..." (Shuster, 2014). Moreover, there were also hints that Russian nationalist biker gang Night Wolves, known for maintaining close ties with Putin, were linked to subversive operation in Crimea. According to Guardian,

Stoked by the Kremlin's narrative that Ukrainian 'fascists', aided and abetted by the CIA, had overthrown a legitimate, pro-Russian government...Kuznetsov [a member of the gang] left his family in Moscow in February 2014 and headed south. He and other bikers actively engaged in Russia's covert invasion of Crimea, swapping leathers for body armour; that summer, they joined Ukraine's separatist insurgency (Losh, 2016, para. 11).

In his interview for Guardian Kuznetsov proclaimed that "...We were the first to be given weapons and to patrol Sevastopol. I am one of the million reasons Crimea finally was annexed" (Losh, 2016, para.13).

\section{ENERGY MEANS}

The energy component of Russian hybrid warfare is also traceable in case of Crimean operation - "In order to establish effective political control of the region, Russia 'nationalized' the Ukrainian company operating in Crimea - Chornomornaftogaz - together with all its energy assets, both onshore and offshore" (Rühle and Grubliauskas, 2015, p. 2). In relation to the seizure of ChornomornaftogazBugryi (2016) adds that:

The State Security Service of Ukraine (SBU) noted that the country had lost access to the 'Petro Hodovanets' and 'Ukraina' drilling rigs since the annexation 
of Crimea. Ukrainian authorities had, therefore, proposed imposing asset freezes and other sanctions against Chernomornaftegas...Ukraine's foreign ministry spokesperson MaryanaBetysa criticized Russia's removal of the rigs, calling it a violation of the United Nations Convention on the Law of the Sea (UNCLOS) and a wide-scale robbery of assets and natural resources by an aggressor state that occupies part of Ukraine's sovereign territory.

As Broad (2014) further points out in supporting these claims,

When Russia seized Crimea in March, it acquired not just the Crimean landmass but also a maritime zone more than three times its size with the rights to underwater resources potentially worth trillions of dollars...the move also extended Russia's maritime boundaries, quietly giving Russia dominion over vast oil and gas reserves while dealing a crippling blow to Ukraine's hopes for energy independence.

Moreover, it seems that Russia used its experience from Crimean socalled independence 'referendum' also in case of poll deciding on signing new electricity power supply treaty with Ukraine. The Russia Today published on its website that

A survey ordered by Vladimir Putin shows Crimea residents would rather break an electricity contract with Kiev, than sign one calling the peninsula part of Ukraine - even if it means further blackouts that began when a pylon bearing power lines was blown up (Crimeans Vote to Give Up Electricity Contract, 2016, para. 1).

Such wording and rhetoric of the survey in addition with such a high rate of conformity seems manipulated: “...94 percent said they were ready to put up with minor disruptions in electricity while Russia is working to provide 100 percent power supply to Crimea in the following months" (Crimeans Vote to Give Up Electricity Contract, 2016, para. 4), plus it is highly improbable that Russia would manage to cover the supply needs by establishing power infrastructure for Crimea within few months: “...it will take many months of complex engineering before Russia can provide Crimea with a secure electricity supply, while Western sanctions over the peninsula's annexation have made it more difficult to buy the best equipment for the job" (Lyrchikova and Winning, 2015, para. 2). The energy warfare reached also to tactical and strategic levels, however, projected in the form of cyber-attacks. The FireEye cybersecurity company published in its report that "In the first publicly documented power outage attributed to a cyber attack, Russian-nexus actors caused blackouts in several regions in Ukraine" (Cyber Attacks on the Ukrainian Grid, 2016, para. 1; Polityuk, 2015). The BlackEnergy3 malware whose older versions are notoriously known to be used by Russia was discovered in cyber-attacks against Ukrainian power grid. 
Moreover "BlackEnergy3 has also been found within organizations that operate critical infrastructure in the United States and abroad" (Cyber Attacks on the Ukrainian Grid, 2016, para. 2; Smith, 2016).

\section{CONCLUSION}

This paper demonstrated that despite the voices of Russian elite and certain scholars, the content of Gerasimov's article cannot be underestimated and simplified to the plain description of the current and future global security environment as well as it cannot be refuted as a basis for new model of warfare strategy directing Russian foreign and security policies. Moreover, as was shown on the case of Crimea, there is no way to dismiss the high probability that this style of warfare will reappear in Russia's future operations given its unprecedented effectiveness. On the contrary, Gerasimov's article provided a theoretical basis not only for a new warfare strategy for Russian military, but even renewed Russian military thinking. This renewed thinking underpinned by Gerasimov appeals for a more inventive, innovative and in the article's rhetoric also more aggressive strategy which strives for revision of the international order with Russia being a more engaged and a more - if not the most - prominent actor.

\section{REFERENCES}

2 Years on Almost All Russians Support Reunification with Crimea. (2016). In Russia Today. Retrieved 13 March, 2017, from https://www.rt.com/ politics/335953-two-years-on-almost-all/

ABBOTT, K. (2016). Understanding and Countering Hybrid Warfare: Next Steps for the North Atlantic Treaty Organization. Retrieved 2 December, 2016, fromhttps://www.ruor.uottawa.ca/bitstream/10393/34813/1/ABBOTT, $\% 20$ Kathleen\%2020161.pdf

All Ukrainian Population Census 2001.(2003-2004). In State Statistics Committee of Ukraine. Retrieved 5 February, 2017, from http://2001.ukrcensus.gov.ua/ eng/

BACHMAN, S.-D., GUNNERIUSSON, H. (2015). Hybrid Wars: The $21^{\text {st }}$ - Century's New Threats to Global Peace and Security. Retrieved 10 December, 2016, from http://www.ajol.info/index.php/smsajms/article/ viewFile/117421/106983

BARTLES, CH. K. (2016). Getting Gerasimov Right. Retrieved 18 December, 2016, from http://usacac.army.mil/CAC2/MilitaryReview/Archives/English/ MilitaryReview_20160228_art009.pdf 
BRANDOM,R.(2014).CyberattacksSpikedAsRussiaAnnexedCrimea. Retrieved 11 February, 2017, from http://www.theverge.com/2014/5/29/5759138/ malware-activity-spiked-as-russia-annexed-crimea

BROAD, W. J. (2014). In Taking Crimea, Putin Gains a Sea of Fuel Reserves. Retrieved 24 March, 2017, fromhttps://www.nytimes.com/2014/05/18/world/ europe/in-taking-crimea-putin-gains-a-sea-of-fuel-reserves.html?_r=2

Bucharest Summit Declaration.(2008). In NATO. Retrieved 24 September, 2016, from http://www.nato.int/cps/en/natolive/official_texts_8443.htm

BUKKVOLL, T. (2014).Russian Special Operations Forces in Crimea and Donbas. Retrieved 13 February, 2017, from http://strategicstudiesinstitute. army.mil/pubs/parameters/issues/Summer_2016/5_Bukkvoll.pdf

BUTTERFIELD, G. (2016). Behind Crimea terror operation: U.S.-NATO escalate war drive against Russia. Retrieved 14 June, 2017, from http://www. workers.org/2016/08/30/behind-crimea-terror-operation-u-s-nato-escalatewar-drive-against-russia/\#.WUDr1OvyjIU

CHOSSUDOVSKY, M. (2016).Two Year Ago: The U.S. has Installed a NeoNazi Government in Ukraine. Retrieved 12 February 2017, from http:// www.globalresearch.ca/the-u-s-has-installed-a-neo-nazi-government-inukraine/5371554

COALSON, R. (2014). Top Russian General Lays Bare Putin's Plan for Ukraine. Retrieved 24 January, 2016, from http://www.huffingtonpost.com/ robert-coalson/valery-gerasimov-putin-ukraine_b_5748480.html

Crimean Govt: Referendum Website Downed by Cyber-Attack from US. (2014). In Russia Today. Retrieved 13 March 2017, from https://www.rt.com/news/ crimea-referendum-attack-website-194/

Crimean Tatars Opposed To Crimea's Return To Fascist Ukraine. (2016). In Novorossia Today. Retrieved 11 February 2017, from http://novorossia.today/ crimean-tatars-opposed-crimeas-return-fascist-ukraine/

Crimeans Vote to Give Up Electricity Contract with Ukraine Even if It Means More Power Cut-offs. (2016). In Russia Today.Retrieved 15 February, 2017, from https://www.rt.com/politics/327673-crimea-vote-contract-ukraine/

CROFT, A., APPS, P. (2014). In NATO Websites Hit in Cyber Attack Linked to Crimea Tension. Retrieved 11 February 2017, from http://www.reuters.com/ article/us-ukraine-nato-idUSBREA2E0T320140316

CUTHBERTSON, A. (2017). In Russian Cyber Attacks Aim to 'Destabilize' the West and NATO. Retrieved 11 February 2017, from http://europe.newsweek. com/russian-cyber-attacks-hacking-nato-fallon-putin-destabilize-west$552050 ? \mathrm{rm}=\mathrm{eu}$

Cyber Attacks on the Ukrainian Grid: What You Should Know. (2016). In FireEye. 
Retrieved 15 February, 2017, from https://www.fireeye.com/content/dam/ fireeye-www/global/en/solutions/pdfs/fe-cyber-attacks-ukrainian-grid.pdf

DARCZEWSKA, J. (2014). The Anatomy of Russian Information Warfare - The Crimean Operation, a Case Study.In Centre for Eastern Studies. Retrieved 10 February, 2017, fromhttps://www.osw.waw.pl/sites/default/ files/the_anatomy_of_russian_information_warfare.pdf

DAVIS, CH. M. (2016). The Ukraine conflict, economic-military power balances and economic sanctions.In Post-Communist Economies. Retrieved 15 December, 2016, fromhttp://www.tandfonline.com/doi/pdf/10.1080/1463 1377.2016.1139301

'Democratic Vote, Govt without Fascists Needed in Ukraine Before Any Talks'. (2014). In Russia Today.Retrieved 15 March, 2015, fromhttps://www.rt.com/ news/ukraine-government-fascists-gysi-997/

Dmitry Medvedev signed the Federal Law On Amendments to the Federal Law On Defence. (2009). In President of Russia. Retrieved February, 2016, from http://en.kremlin.ru/events/president/news/5935

ELEFTHERIOU-SMITH, L.-M. (2015). Putin reveals the moment he ordered the plot to take control of Crimea. In Independent. Retrieved 17 March, 2017 from http://www.independent.co.uk/news/world/asia/putin-reveals-themoment-he-ordered-the-plot-to-take-control-of-crimea-10096351.html

FLEMING, B. P. (2011). The Hybrid Threat Concept: Contemporary War, Military Planning and the Advent of Unrestricted Operational Art. Retrieved 3 December, 2016, from http://indianstrategicknowledgeonline.com/ web/2753.pdf

Foreign Policy Concept of the Russian Federation. (2016). In The Ministry of Foreign Affairs of the Russian Federation. Retrieved 2 February, 2017, from http://www.mid.ru/en/foreign_policy/official_documents/-/asset_publisher/ CptICkB6BZ29/content/id/2542248

GALEOTTI, M. (2014).Hybrid War on GibridnayaVoina? Getting Russia's nonlinear military challenge right. Retrieved 24 March, 2017, from https://books. google.sk/books?id=KDW8DQAAQBAJ\&pg=PA25\&lpg=PA25\&dq=mo naghan + russian + hybrid + war\& source $=$ bl\&ots $=$ pd91SyKq- $1 \&$ sig $=\mathrm{QYYpW}$ mhlWbQxMsNgfRHv3kF93Aw\&hl=en\&sa=X\&ved=0ahUKEwj87uLpnSAhWJFywKHSvpCpUQ6AEIQDAG\#v=onepage \& $\mathrm{q}=\operatorname{trade} \% 20$ opportunities\&f=false

GEERS, K. (2015). Cyber War in Perspective: Russian Aggression Against Ukraine. In: Lewis, A. J. (Ed.), 'Compelling Opponents to Our Will' : The Role of Cyber Warfare in Ukraine (pp. 39-47). Talinn: NATO Cooperative Cyber Defence Centre of Excellence 
GILES, K. (2016). The Next Phase of Russian Information Warfare. Retrieved 11 February 2017, from https://issuu.com/natostratcomcoe/docs/keir_giles_ public_20.05.2016

GLENN, R. W. (2009). Thoughts on "Hybrid" Conflict In: Small Wars Journal. Retrieved 2 December, 2016, from http://smallwarsjournal.com/printpdf/7849 HARDING, L. (2014). Kiev's Protesters: Ukraine Uprising Was No Neo-Nazi Power-grab. Retrieved 12 February 2017, from https://www.theguardian. com/world/2014/mar/13/ukraine-uprising-fascist-coup-grassroots-movement HASHIM, A.S. (2015). Hybrid War: ISIS and Russia in Action, A Comparative Study of Non-State and State Forms of Non-Linear Warfare. Retrieved 10 December, 2016, from https://www.doria.fi/bitstream/handle/10024/117602/ HASHIM\%20Ahmed_WG\%206_Abstract_Hybrid\%20War-ISIS $\% 20$ and $\% 20$ Russia $\% 20$ in $\% 20$ Action, $\% 20 \mathrm{~A} \% 20$ Comparative $\% 20$ Study $\% 20$ of $\% 20$ Non-State $\% 20$ and $\% 20$ State $\% 20$ Forms $\% 20$ of $\% 20$ Non-Linear $\% 20$ Warfare.pdf? sequence $=2$

HOFFMAN, F. G. (2009). Hybrid Warfare and Challenges. Retrieved 2 December, 2016, from http://smallwarsjournal.com/documents/jfqhoffman. pdf

HOSMER, S.T. (n.d.). The Information Revolution and Psychological Effects. Retrieved 11 December, 2016, from https://www.rand.org/content/dam/rand/ pubs/monograph_reports/MR1016/MR1016.chap8.pdf

JAITNER, M., MATTSSON, P.A. (2015).Russian Information Warfare of 2014. Retrieved 11 February, 2016, from https://ccdcoe.org/cycon/2015/ proceedings $/ 03$ jaitner_mattsson.pdf

JONES, S. (2014). Ukraine: Russia's New Art of War. In Financial Times. Retrieved 18 December, 2016, fromhttps://www.ft.com/content/ea5e82fa2e0c-11e4-b760-00144feabdc0

JOSAN, A., VOICU, C. (2015). Hybrid Wars in the Age of Asymmetric Conflicts. Review of the Air Force Academy, 28(1), 49-52. Retrieved 2 December, 2016, from http://www.afahc.ro/ro/revista/2015_1/49.pdf

JOVANOVSKI, K. (2014). Crimea's Information War.Retrieved 11 February 2017, from http://www.aljazeera.com/indepth/features/2014/03/crimeainformation-war-2014315111243167677.html

KASAPOGLU, C. (2015). Russia's Renewed Military Thinking: Non-Linear Warfare and Reflexive Control. In NATO Research Division of the NATO Defence College, Rome.Retrieved 2 December, 2016, from http://cco.ndu. edu/Portals/96/Documents/Articles/russia's\%20renewed\%20Military\%20 Thinking.pdf

KOFMAN, M., ROJANSKY, M. (2015).A Closer Look at Russia's "Hybrid 
War"? Retrieved 18 December, 2016, fromhttps://www.wilsoncenter.org/ sites/default/files/7-KENNAN\%20CABLE-ROJANSKY\%20KOFMAN.pdf

LANOSZKA, A. (2016). Russian Hybrid Warfare and Extended Deterrence in Eastern Europe.International Affairs, 92(1), 175-195. Retrieved 18 December, 2016, fromhttp://www.alexlanoszka.com/LanoszkaIAHybrid.pdf

LILLY, B. (2014).Russian Foreign Policy Towards Missile Defence: Actors, Motivations, and Influence. Retrieved 28 September, 2016, from https:// books.google. .sk/books?id=8q9hBAAAQBAJ\&pg=PP1\&lpg=PP1\&dq=lilly+russian+Foreign+Policy+toward+Missile+Defense:+Actors, +Motivations, + and \& source $=$ bl\&ots $=$ zs U0-R2YXL\&sig=FSwdSLnCny4romKh5e5uvTpLk4A\&hl=en\&sa $=$ X\&ved $=0$ ahUKEwiitqLMgrPPAhXqAMAKHX36BHUQ6AEIMDAD\#v=onepage $\& \mathrm{q}=1 \mathrm{illy} \% 20 \mathrm{russian} \% 20$ Foreign $\% 20$ Policy $\% 20$ toward $\% 20$ Missile $\% 20$ Defense $\% 3 \mathrm{~A} \% 20 \mathrm{Ac}-$ tors $\% 2 \mathrm{C} \% 20$ Motivations $\% 2 \mathrm{C} \% 20$ and $\& \mathrm{f}=$ false

Lithuania Confirms Presence of US Special Forces As a 'Deterrence against Russian Aggression'. (2017). Russian Special Operations Forces in Crimea and Donbas. Retrieved 13 February, 2017, from https://www.rt.com/ news/372602-lithuania-us-special-forces/

LOSH, J. (2016). Putin's Angels: The Bikers Battling for Russia in Ukraine. Retrieved 13 February, 2017, from https://www.theguardian.com/world/2016/ jan/29/russian-biker-gang-in-ukraine-night-wolves-putin

LUXMORE, M. (2015).Putin Strokes Fear of Phantom Fascists in Crimea. Retrieved 11 February 2017, from http://europe.newsweek.com/putin-stokesfear-phantom-fascists-crimea-317856? $\mathrm{rm}=\mathrm{eu}$

LYRCHIKOVA, A., WINNING, A. (2015). Russia-annexed Crimea Faces Long Road to Power Security. In Reuters. Retrieved 15 February 2016, from http://www.reuters.com/article/us-ukraine-crisis-crimea-power-insightidUSKBN0TW06G20151213

LYUBASHENKO-ZASZTOWT, K. (2012). NATO-Ukraine Partnership. Retrieved 9 February 2017, from http://cenaa.org/analysis/nato-ukrainepartnership/

MARXSEN, CH. (2014). The Crimea Crisis - An International Law Perspective. Retrieved 8 August, 2017, from http://www.mpil.de/files/pdf4/ Marxsen_2014_-_The_crimea_crisis_-_an_international_law_perspective.pdf MCCUEN, J. J. (2008). Hybrid Wars. Retrieved 11 December, 2016, from http:// www.au.af.mil/au/awc/awcgate/milreview/mccuen08marapr.pdf

MCDERMOTT, R. N. (2016). Does Russia Have a Gerasimov Doctrine? Parameters, 46(1), 97-105. Retrieved 24 March, 2017, fromhttp://ssi. armywarcollege.edu/pubs/parameters/issues/Spring_2016/12_McDermott.pdf 
MEISTER, S., PUGLIERIN, J. (2015).Perception and Exploitation: Russia's Non-Military Influence in Europe Retrieved 15 January, 2016, from https:// dgap.org/en/article/getFullPDF/27185

MERCOURIS, A. (2016). Shootout in Crimea: Russia's "Anti-terrorism Agency" (FSB) vs Ukrainian Saboteurs Retrieved 12 February, 2017, from http://www.globalresearch.ca/shootout-in-crimea-russias-fsb-vs-ukrainiansaboteurs $/ 5540655$

MILNE, R., JONES, S., HILLE, K. (2014). Russian Air Incursions Rattle Baltic States. Retrieved 15 March, 2017, from https://www.ft.com/ content/9d016276-43c3-11e4-baa7-00144feabdc0

MONAGHAN, A. (2016). Putin's Way of War: The 'War' in Russia's 'Hybrid Warfare'. Parameters, 45(4), 65-74. Retrieved 24 January, 2016, from http://www.strategicstudiesinstitute.army.mil/pubs/parameters/issues/ Winter_2015-16/9_Monaghan.pdf

MORRIS, V. R. (2015). Leveraging Lietuva: Establishing a $21^{\text {st }}$ Century Nonlinear Warfare Centre of Excellence. Retrieved 4 December, 2016, from $\mathrm{http}$ //www.stratcomcoe.org/victor-r-morris-leveraging-lietuva-establishing21st-century-nonlinear-warfare-centre-excellence

MURPHY, M. (2016).Understanding Russia's Concept for Total War in Europe. In The Heritage Foundation.Retrieved 11 February, 2016, from http://www. heritage.org/defense/report/understanding-russias-concept-total-war-europe

New Russian Bill Condemns 1954 Transfer of Crimea to Ukraine as 'Illegal'. (2015). InThe Moscow Times. Retrieved 13 March 2017, from https:// themoscowtimes.com/news/new-russian-bill-condemns-1954-transfer-ofcrimea-to-ukraine-as-illegal-43588

PADDOCK, A.H. (1990). US Military Psychological Operations: Past, Present, and Future. In: Radvanyi, J. (Ed.), Psychological Operations and Political Warfare in Long-term Strategic Planning. Retrieved December 11, 2016 from https://books.google.sk/books?id=DUZJcDOUKtsC\&pg=PA19\&lp$\mathrm{g}=\mathrm{PA} 19 \& \mathrm{dq}=$ psychological + operations $\&$ source $=$ bl\&ots $=$ MMv8UIFf4b\&sig $=6 Z 5$ YFjff9 qPChli6UV9FnWmNpSQ\&hl $=$ en\& $s a=X \& v e d=0 a-$ hUKEwjundmw5-vQAhUIIcAKHZP4Akw4KBDoAQgqMAM\#v=onepage $\& \mathrm{q}=$ psychological $\% 20$ operations $\& \mathrm{f}=$ false

PAGANINI, P. (2014). Crimea - Is Russia Adopting the Same Cyber Strategy Used in Georgia?. Retrieved 11 February, 2016, from http://securityaffairs. co/wordpress/22781/cyber-warfare-2/crimea-russia-cyber-strategy.html

PAVLENKO, O. (2016). The European Union and Ukraine: Cooperation for the Strengthening of Energy Security. In European Economic and Social Committee.Retrieved 7 February, 2017 from http://www.eesc.europa.eu/ 
resources/docs/energy_ukr.pdf

PAWLAK, P. (2015). At a Glance: Understanding Hybrid Threats. Retrieved

2 December, 2016, fromhttp://www.europarl.europa.eu/RegData/etudes/ ATAG/2015/564355/EPRS_ATA(2015)564355_EN.pdf

PISHCHIKOVA, K., OGRYZKO, O. (2014). Civic Awakening: The Impact of Euromaidan on Ukraine's Politics and Society. In Fundación para las RelacionesInternacionales y el Diálogo Exterior.Retrieved 6 February, 2017, fromhttp://fride.org/descarga/WP_124_Civic_awakening.pdf

PLOEG, DE CH. (2016).In Ukraine Europe Is Collaborating With Oligarchs and Fascists. Retrieved 12 February, 2017, from https://international.sp.nl/ nieuws/2016/02/in-ukraine-europe-is-collaborating-with-oligarchs-andfascists

PLOKHY, S. (2014). The Ghosts of Pereyaslav: Russo-Ukrainian Historical Debates in the Post-Soviet Era. Europe-Asia Studies, 53(3), 489-505.

Public Opinion Survey Residents of Ukraine. (2014). In International Republican Institute. Retrieved 3 August 2017, from http://www.iri.org/sites/default/ files/2014\%20April\%205\%20IRI\%20Public\%20Opinion\%20Survey $\% 20$ of $\% 20$ Ukraine $\% 2 \mathrm{C} \% 20 \mathrm{March} \% 2014-26 \% 2 \mathrm{C} \% 202014$.pdf

Public Opinion Survey Residents of the Autonomous Republic of Crimea. (2013). In International Republican Institute. Retrieved 6 August 2017, from http://www.iri.org/sites/default/files/2013\%20October\%207\%20Survey\%20 of\%20Crimean\%20Public\%20Opinion,\%20May\%2016-30,\%202013.pdf

Putin Acknowledges Russian Military Servicemen Were in Crimea. (2014). In Russia Today. Retrieved 12 February 2017, fromhttps://www.rt.com/news/ crimea-defense-russian-soldiers-108/

Putin Says Crimea Not Annexed By Russia, It Was 'Reunified'. (2016). In Radio Free Europe/Radio Liberty. Retrieved 13 March 2017, from http://www.rferl. org/a/putin-says-crimea-not-annexed-was-reunified-with-russia/27996702. html

Putin: Russia Could Not 'Abandon' Crimea. (2015). In Defense News. Retrieved 13 March 2017, from http://www.defensenews.com/story/defense/international/ europe/2015/03/09/putin-russia-could-not-abandon-crimea/24673619/

Putin's Gambit. (2014). In TheEconomist. Retrieved 11 February 2017, from http://www.economist.com/news/europe/21601899-russian-presidentsunexpected-concessions-ukraine-reflect-fact-he-has-already-got

RÜHLE, M., GRUBLIAUSKAS, J. (2015).Energy as a Tool of Hybrid Warfare. Retrieved 13 February, 2017, from https://www.files.ethz.ch/isn/190791/ rp_113.pdf

RUSI, A. (2014). Espionage as a Method of a Modern Hybrid War. In: Wilfried 
Martens Centre for European Studies and Toivo Think Thank (Ed.), Seminar Paper (pp. 11-14). Retrieved 15 December, 2016, from https://www. toivoajatuspaja.fi/@Bin/230378/Toivo_Martens_TinkerTailor_A4_Digi_ LR.pdf

Russia Broadens Anti-incitement Law to Include Separatism. (2014). In The Times of Israel. Retrieved 12 February, 2017, from http://www.timesofisrael. com/russia-broadens-anti-incitement-law-to-include-separatism/

Russia Starts Giving Out Passports to Ukraine's ex-Berkut Officers Pelted With 'Threats'. (2012). Security Strategy: Why Arms? In Russia in Global Affairs. Retrieved 18 November, 2016, from http://eng.globalaffairs.ru/pubcol/ Security-Strategy-Why-Arms-15716

Russian Bill Seeks To Nullify Crimea's Soviet-Era Transfer To Ukraine. (2014). In Radio Free Europe/Radio Liberty. Retrieved 13 March, 2017, from http:// www.rferl.org/a/russia-ukraine-crimea-transfer-nullify/26757359.html

Russian FSB Agents in Crimea Charge Journalists, Interrogate Another. (2014). In Russia Today.Retrieved 13 February, 2017, from https://www.rt.com/news/ berkut-police-russian-passports-266/

Russian FSB Agents in Crimea Charge Journalists, Interrogate Another. (2014). In Russia Today.Retrieved 13 February, 2017, from https://www.rt.com/news/ berkut-police-russian-passports-266/

Russian FSB Foils Terrorist Attacks Plotted by Ukrainian Intel Agents in Crimea. (2016). In Russia Today.Retrieved 12 February 2017, from https://www. rt.com/news/355385-fsb-ukraine-terrorist-attacks/

Russian Ministry of Defence Releases Shocking Images of Crimea War Games. (2016). In Sputnik International. Retrieved 11 February, 2017, from https:// sputniknews.com/russia/201609111045183103-russia-crimea-war-gamesmilitary/

Russian National Security Strategy.(2015). In Spanish Institute for Strategic Studies.Retrieved 2 February, 2017, from http://www.ieee.es/Galerias/ fichero/OtrasPublicaciones/Internacional/2016/Russian-National-SecurityStrategy-31Dec2015.pdf

ŠEŠELGYTÉ, M. (2014). Can Hybrid War Become the Main Security Challenge for Eastern Europe? Retrieved 6 February, 2016, from http://www. europeanleadershipnetwork.org/can-hybrid-war-become-the-main-securitychallenge-for-eastern-europe_2025.html

SHUSTER, S. (2014). Ukrainian Base in Crimea Resists Russian Raid. Retrieved 13 February, 2017, from http://time.com/16294/russia-crimea-sevastopol/

SLOBODIAN, N. (2016). Energy Instruments of "Hybrid Warfare".In Stratfor. Retrieved 15 December, 2016, from https://www.stratfor.com/the-hub/ 
energy-instruments- $\% \mathrm{E} 2 \% 80 \% 9$ Chybrid-warfare $\% \mathrm{E} 2 \% 80 \% 9 \mathrm{D}$

SMITH, A.D. (2016). Nato Countries Begin Largest War Game in Eastern Europe Since Cold War. Retrieved 2 March 2017, from https://www.theguardian. com/world/2016/jun/06/nato-launches-largest-war-game-in-eastern-europesince-cold-war-anaconda-2016

SNEGOVAYA, M. (2015).Putin's Information Warfare in Ukraine - Soviet Origins of Russia's Hybrid Warfare.In Institute for the Study of War. Retrieved 10 February 2017, from http://understandingwar.org/sites/default/ files/Russian\%20Report \%201\%20Putin's\%20Information\%20Warfare $\% 20$ in $\% 20$ Ukraine-\%20Soviet\%20Origins $\% 20$ of $\% 20$ Russias $\% 20 H y b r i d \% 20$ Warfare.pdf

SNYDER, T. (2014).The Battle in Ukraine Means Everything. Retrieved 11 February 2017, fromhttps://newrepublic.com/article/117692/fascism-returnsukraine

SONNE, P. (2014). Across Crimea, a Sudden Militarization. Retrieved 12 February, 2017, from https://www.wsj.com/articles/SB10001424052702303 801304579411512937763466

SRIDHARAN, V. (2014). Crimea Chaos: Russia Issues Passports to Ukraine Riot Police Disbanded by Kiev's Interim Government. Retrieved 12 February, 2017, from http://www.ibtimes.co.uk/crimea-chaos-russia-issues-passportsukraine-riot-police-disbanded-by-kievs-interim-government-1438447

Statistics and Facts on Ukraine.(n.d.).In Statista.Retrieved 6 February 2017, from https://www.statista.com/topics/2473/ukraine/

SVETOKA et al., (2016).Social Media as a Tool of Hybrid Warfare. Retrieved December 11, 2016 from http://www.stratcomcoe.org/download/file/fid/5314 The Moscow Times. (2014). More Than Half of Ukrainians Want to Join EU, Poll Shows. Retrieved 8 February, 2017, from https://themoscowtimes.com/ articles/more-than-half-of-ukrainians-want-to-join-eu-poll-shows-32735

The Transfer of the Crimea to the Ukraine.(2005). In International Committee for Crimea.Retrieved 11 August, 2016, from http://www.iccrimea.org/historical/ crimeatransfer.html

TIMOFEYCHEV, A. (2016). Are Ukrainian Agents Really Trying to Destabilize Crimea From Within? Retrieved 12 February, 2017, from http://rbth.com/ politics_and_society/2016/11/14/are-ukrainian-agents-really-trying-todestabilize-crimea-from-within_647619

TISMANEANU, V. (1995). Political Culture and Civil Society in Russia and the NewStates of Eurasia.[GoogleBooks version]. RetrievedAugust 11,2016, from https://books.google.sk/books?id=OU0_dc1VqqIC\&pg=PA177\&lpg=PA17 $7 \& \mathrm{dq}=$ russia + and + ukraine + common + origin $\&$ source $=$ bl\&ots $=$ TVhWN3PH 
WB\&sig=IlIwK-NDgyNicccadmjJL0udXNU\&hl=en\&sa=X\&ved=0ahUKE wjghobr57fOAhWC2xoKHcfLBeIQ6AEISDAH\#v=onepage \&q=russia $\% 20$ and $\% 20$ ukraine $\% 20$ common $\% 20$ origin\& $\mathrm{f}=$ false

TRAYNER, D. (2016). Russia Would Destroy NATO In Just 60 Hours - Shock Warning. Retrieved 12 February, 2017, from http://www.dtic.mil/dtic/tr/ fulltext/u2/a341002.pdf

TV Channel of RU Ministry of Defence Claims that Crimea Was Russian Already 160 Million Years Ago. (2016). In EU Mythbuster. Retrieved 11 February, 2017, from https://twitter.com/euvsdisinfo/status/783973362334896128

Ukraine: Trade Statistics 2015. (n.d.).In GlobalEdge.Retrieved 6 February 2017, from https://globaledge.msu.edu/countries/ukraine/tradestats

Ukraine-EU Relations.(2012). In Ministry of Foreign Affairs of Ukraine. Retrieved 9 February, 2017, from http://ukraine-eu.mfa.gov.ua/en/ukraineeu/relations

Ukrainian Commandos Planning Attacks with Explosives \& Weapons Detained in Crimea - FSB.(2016). In Russia Today.Retrieved 12 February 2017, from https://www.rt.com/news/366192-ukrainian-commandos-attacks-crimea/

Ukrainian Special Forces Regiment Joins Other Units in Refusal to March Against Crimea. (2014). Russian Special Operations Forces in Crimea and Donbas. Retrieved 13 February, 2017, from https://www.rt.com/news/ crimea-russian-special-forces-560/

Ukrtelecom Shuts Down Communication Services in Crimea Due to Attack on Local Branch. (2015). In Unian Information Agency. Retrieved 11 February, 2017, from https://www.unian.info/society/1042419-ukrtelecom-shutsdown-communication-services-in-crimea-due-to-attack-on-local-branch. html

US Plays Double With Russia After Plans for Base in Crimea Failed - Experts. (2015). In Sputnik News. Retrieved 13 March 2017, from https://sputniknews. com/analysis/201503161019588225/

VASILESCU, V. (2016).NATO's Future Blitzkrieg Against Russia: The Battle For Air Supremacy. Retrieved 12 February, 2017, from http://katehon.com/ article/natos-future-blitzkrieg-against-russia-battle-air-supremacy

WALKER, S. (2013). Vladimir Putin offers Ukraine financial incentives to stick with Russia. Retrieved 6 August, 2017, from https://www.theguardian.com/ world/2013/dec/17/ukraine-russia-leaders-talks-kremlin-loan-deal

ZAYETS, S., MATVIYCHUK, O., PECHONCHYK, T., SVYRYDOVA, D., SKRYPNYK, O. (2016). The Peninsula of Fear: Chronicle of Occupation and Violation of Human Rights in Crimea. Retrieved 12 February, 2017, from http://helsinki.org.ua/wp-content/uploads/2016/05/PeninsulaFear_Book_ 


\section{ENG.pdf}

ZAYETS, S., MATVIYCHUK, O., PECHONCHYK, T., SVYRYDOVA, D., SKRYPNYK, O. (2016). The Peninsula of Fear: Chronicle of Occupation and Violation of Human Rights in Crimea. Retrieved 12 February, 2017, from http://helsinki.org.ua/wp-content/uploads/2016/05/PeninsulaFear_Book_ ENG.pdf

ZINETS, N. (2014). Ukraine Hit by 6,500 Hack Attacks, Sees Russian 'Cyberwar'. Retrieved 11 February, 2017, from http://www.reuters.com/ article/us-ukraine-crisis-cyber-idUSKBN14I1QC 